\title{
MAKNA KEBAHAGIAAN DAN KEHARMONISAN RUMAH TANGGA DALAM PERSPEKTIF PSIKOLOGI
}

\author{
Oleh: \\ Mohamat Hadori \& Minhaji \\ Universitas Ibrahimy Situbondo \\ hadorimohamat@mail.ugm.ac.id \\ Moh_Minhaji@yahoo.co.id
}

\begin{abstract}
:
Happiness and harmony of household come from the love, emotional maturity, and intensity of communication that is built up from each individual in the household. The characteristic of a sense of love of the household is harmonious relationship especially between the husband and wife. In ddition to being a form of character and the personality of parents is also a means of forming the character and personality of child. Harmony of the home sourced from the harmony of each individual in the household that has performed its duties, functions, and responsibilities is a manifestation of an emotional maturity of each individual in the household. On the other hand, harmony of the household is a factor of communication intensity in family that runs effectively. The intensity of communication of the household has a considerable influence on whether or are not harmony Conversely relationships of family, ineffective communication is often the cause of harmony in a family relationship.
\end{abstract}

Key Words: Kebahagiaan, Keharmonisan, Cinta, Kematangan, Intensitas Komunikasi, Rumah Tangga

\section{A. Pendahuluan}

Setiap individu dalam mengarungi kehidupan rumah tangga tidak akan pernah lepas dari berbagai macam kondisi psikologis yang silih berganti mewarnainya, mulai dari kondisi yang menyenangkan maupun yang menyedihkan. Kebahagiaan merupakan tujuan tertinggi bagi setiap individu yang membangun kehidupan rumah tangga. Kebahagiaan setiap individu dalam kehidupan rumah tangga dapat diukur dengan adanya rasa cinta, keharmonisan, dan tingkat kematangan emosional pada masingmasing pasangan, serta intensitas komunikasi dengan pasangan. ${ }^{1}$

${ }^{1}$ Lucas, T., Parkhill, M. R., Wendorf, C. A., Imamoglu, E. O., Weisfeld, C. C., Weisfeld, G. E., \& Shen, J. Cultural and Evolutionary Components of Marital Satisfaction : A 
Individu, baik suami maupun isteri dengan level yang lebih tinggi tingkat kebahagiaan hidupnya mungkin menjadi paling lebih lama dalam menikmati kebahagian dalam rumah tangganya. Persamaanya adalah individu dengan tingkat paling rendah tingkat kebahagiaan hidupnya mungkin menjadi lebih lama tingkat kelemahan kebahagiaan dalam rumah tangganya. Individu yang telah menikah, tetapi dalam kehidupannya mengalami ketidakbahagiaan, berarti individu tersebut mengalami kemunduran dan mayoritas kurang memiliki tingkat kesejahteraan secara psikologis dalam hidupnya. ${ }^{2}$

Keluarga yang bahagia adalah sebuah bangunan rumah tangga yang dibuat oleh seorang pasangan suami isteri yang menunjukkan pengertian satu sama lain atau kepuasannya atau pengalamannya di dalam hubungan pernikahan. Pandangan menganai kebahagian dalam pernikahan melewati lensa psikologi keluarga mempunyai implikasi untuk memahami secara lengkap tentang hubungan suami isteri dan peran serta fungsinya masing-masing. Kebahagian dalam rumah tangga memiliki potensi untuk mempertinggi fungsi dan bukan kebalikannya. Kebahagian dalam rumah tangga adalah situasi yang di dalamnya terdapat suatu kekuatan dan kebajikan. ${ }^{3}$

Potensi mekanisme hubungan dalam rumah tangga yang dipenuhi rasa cinta adalah jalan untuk menuju keharmonisan dan kebahagiaan dalam keluarga. Sebab, telah ditemukan fakta-fakta bahwa kebahagiaan yang tinggi dalam rumah tangga menjadi faktor penyeimbang dalam mengambil keputusan. Ada beberapa sebab kebahagian yang diperlukan dalam rumah tangga, salah satunya adalah pentingnya memupuk intimasi hubungan dan membantu perkembangan intimasi tersebut. ${ }^{4}$

Menumbuhkan kebahagiaan dalam rumah tangga dibutuhkan sebuah cinta. Menurut Sternberg, cinta itu mengandung komponen

Multidimensional Assessment of Measurement Invariance. (Journal of Cross-Cultural Psychology. Vol. 39, 109-123. Sage Publications, 2008).

2 Adler, M.A. German Unification as a Turning Point in East German Woman's Life Course : Biographical Changes in Work and Family Roles. Sex Roles (Journal of Research. http://www.looksmart.com. 2002).

${ }^{3}$ Allen, T.D. Applicant Gender and Family Structure : Effects on Perceived Relocation Commitment and Spouse Resistance. Sex Roles (Journal of Research. http://www.looksmart.com. 2002).

4 Snyder, C.R. \& Shane, J. L. Positive Psychology The Scientific And Practical Exploration Of Human Strengths. 2006); Frisco, M. L. \& Williams, K. Perceived Housework Equity, Marital Happiness, and Divorce in Dual-Earner Households. (Journal of Family Issues. Vol. 24, No. 1, 51-73. Sage Publications, 2003).

6 JURNAL LISAN AL-HAL 
keintiman (intimacy), gairah (passion) dan komitmen (commitment). Dari ketiga komponen tersebut dapat membentuk delapan kombinasi jenis cinta yaitu nonlove, liking, infatuation love, empty love, romantic love, companionate love, fatous love, consummate love. ${ }^{5}$ Cinta adalah sebuah kisah yang ditulis oleh setiap individu. Kisah tersebut merefleksikan kepribadian, minat dan perasaan seseorang terhadap suatu hubungan. Kisah pada setiap individu berasal dari "skenario" yang sudah dikenalnya, baik dari orang tua, pengalaman, cerita, dan sebagainya. Kisah ini, biasanya mempengaruhi individu dalam mengambil sikap dan tindakan dalam sebuah hubungan. ${ }^{6}$

Sebuah bangunan rumah tangga, di dalamnya sudah barang tentu juga mendambakan seatu kehidupan yang memiliki keseimbangan dalam berbagai aspeknya, seperti keharmonisan dan beberapa pilar penopang psikologis lainnya. Keseimbangan berbagai aspek tersebut di dalam kehidupan rumah tangga perlu dipupuk dan dijaga. Dalam hal ini, masingmasing anggota keluarga (suami dan isteri) hendaknya mengetahui tugas, kewajiban, dan tanggung jawabnya secara menyeluruh, ${ }^{7}$ karena hal tersebut memiliki peranan yang amat penting dalam menciptakan keseimbangan hubungan yang harmonis di dalam rumah tangga. ${ }^{8}$

Keharmonisan dalam rumah tangga yang diharapkan semua orang, erat kaitannya dengan kepercayaan. Bila seorang suami tidak percaya pada seorang isteri atau sebaliknya, maka simpul-simpul cinta dan kasih sayang akan sulit dirasakan kedua belah pihak. Secara kasar dan kasat mata, kedua belah pihak akan sama-sama rugi bila tidak saling percaya dan anak akan menjadi korban dan akan kehilangan simpul kasih sayang dari orang tuanya. ${ }^{9}$

Keharmonisan dalam rumah tangga akan terbentuk dari keakraban masing-masing anggota keluarga (suami dan isteri). Kondisi ini bisa 1986).

${ }^{5}$ Sternberg, R. J. A Triangular Theory of Love. (Psychology Review, 93, 119-135,

${ }^{6}$ Carroll, J. S., Badger, S., \& Yang, C. The Ability to Negotiate or the Ability to Love? : Evaluating the Developmental Domains of Marital Competence. (Journal of Family Issues. Vol. 27, No. 7, 1001-1032. Sage Publications, 2006).

7 Kidman, A. Family Life; Adapting to Change A self Help Manual. (Sydney: Biochemical \& general service, 1995).

${ }^{8}$ Lambrecht, J. \& Lievens, J. Pruning the Family Tree: An Unexplored Path to Family Business Continuity and Family Harmony. (Family Business Review, Vol. 21, No. 4, Sage Publications, 2008).

9 Widhiati, G. W. Hubungan antara Kepercayaan dan Keharmonisan Keluarga. http://keluargaharmonis.com/hubungan-antara-kepercayaan-dan-keharmonisankeluarga, 2010). 
terjadi, jika suami atau isteri mampu menciptakan suatu hubungan yang baik dan teratur. ${ }^{10}$ Bila dalam bangunan rumah tangga bisa terjadi jalinan hubungan yang harmonis, maka anak akan lebih mudah untuk tumbuh secara wajar dan sehat baik secara fisik maupun psikologis. Jadi, menjaga keharmonisan rumah tangga itu merupakan hal yang mutlak dilakukan demi menciptakan sebuah keluarga yang tenteram dan sejahtera. ${ }^{11}$

Keharmonisan hubungan dalam rumah tangga tetap akan terjaga, jika setiap dari anggota keluarga tersebut mengerti tanggung jawab masing-masing dan mau melaksanakannya dengan baik dan konsisten. ${ }^{12}$ Demikian pula dengan hak yang dimiliki dapat diperoleh sesuai porsinya tanpa menuntut yang berlebih. Selain itu, keharmonisan rumah tangga tetap akan terjaga, jika dari masing-masing anggota keluarga berupaya membangun terciptanya suasana surga dalam rumah. Maksud surga di sini adalah segala sesuatu yang membuat setiap anggota keluarga selalu merasa dekat (intim) satu sama lain dan betah untuk selalu tinggal di rumah, karena telah tercipta suasana yang tenteram dan sejahtera seperti yang telah disebutkan di atas. ${ }^{13}$

Keharmonisan dalam rumah tangga bersumber dari keseimbangan antar anggota keluarga (suami atau isteri) dalam melaksanakan tugas, fungsi, dan tanggung jawabnya ${ }^{14}$ masing-masing yang merupakan manifestasi dari sebuah kematangan emosional dari masing-masing anggota keluarga yang perkembangannya seiring dengan pertambahan usia. Karena kematangan emosional setiap individu sangat ditentukan oleh faktor usia dan setiap individu mengalami perbedaan di dalam mencapai kematangan emosional tersebut. 15

${ }^{10}$ Crittenden, P. M. \& Dallos, R. All in the Family: Integrating Attachment and Family Systems Theories. (Clinical Child Psychology and Psychiatry. Vol. 14, No. 3, 389-409. Sage Publications, 2009).

11 Ahira, A. Menghindari Perpecahan dan Menjaga Keharmonisan Keluarga. http://www.anneahira.com/menjaga-keharmonisan-keluarga.htm., 2010).

12 Kidman, A. Family Life; Adapting to Change A self Help Manual.

13 Patrick, S., Sells, J. N., Giordano, F. G., \& Tollerud, T. R. Intimacy, Differentiation, and Personality Variables as Predictors of Marital Satisfaction. (The Family Journal: Counseling and Therapy for Couples and Families, Vol. 15, No. 4, 359-367. Sage Publications. 2007); Martyn, K. K., Cherry, C. J. L., Villarruel, A. M., Cabriales, E. G., Zhou, Y., Ronis, D. L., \& Eakin, B. Mexican Adolescents' Alcohol Use, Family Intimacy, and ParentAdolescent Communication. (Journal of Family Nursing. Vol. 15, No. 2, 152-170. Sage Publications, 2009).

${ }^{14}$ Kidman, A. Family Life; Adapting to Change A self Help Manual.

15 Srivastava, S., John, O. P., Gosling, S. D., \& Potter, J. Development of Personality in Early and Middle Adulthood: Set Like Plaster or Persistent Change?. (Journal of Personality and Social Psychology. Vol. 84, No. 5, 1041-1053. American Psychological Association, 
Faktor fisik-fisiologis individu dalam rumah tangga juga belum tentu mutlak sepenuhnya mempengaruhi perkembangan kematangan emosional, karena kematangan emosional merupakan salah satu fenomena psikis bagi setiap individu. Faktor determinan psikis terhadap kematangan emosional sangat beragam, baik faktor pola asuh (parenting style) orang tua sebelumnya, lingkungan sosial, dan pendidikan. Jelasnya, setiap individu dalam sebuah keluarga (suami-isteri) pada usia yang sama belum tentu mencapai tarap kematangan emosional yang sama pula. ${ }^{16}$

Dengan demikian, setiap pasangan suami-isteri yang matang secara emosi adalah sebuah pasangan yang telah menemukan suatu prinsip yang kuat dalam hidupnya. ${ }^{17}$ Masing-masing dari pasangan suami-isteri tersebut saling menghargai prinsip satu sama lain dan menghormati perbedaan-perbedaan yang ada. ${ }^{18}$ Di sisi lain, masing-masing suami atau isteri selalu menepati janjinya dan selalu bertanggung jawab dengan apa yang telah diucapkannya. Sebab, kematangan emosional yang dimiliki oleh individu akan dapat mengontrol perilaku-perilaku impulsif yang dapat merusak energi yang dimiliki oleh tubuh, individu dapat melakukan halhal yang bersifat positif dibandingkan memenuhi nafsu yang dapat merusak dan bersifat merusak dalam bangunan rumah tangga. ${ }^{19}$

Selain faktor kematangan emosional dari masing-masing anggota keluarga yang dapat membentuk keharmonisan dalam sebuah bangunan rumah tangga adalah faktor intensitas komunikasi bagi pasangan suamiisteri yang berjalan efektif. ${ }^{20}$ Intensitas komunikasi dalam rumah tangga memiliki pengaruh yang cukup besar terhadap baik tidaknya suatu keharmonisan hubungan dalam bangunan rumah tangga. Sebaliknya, komunikasi yang tidak efektif sering menjadi penyebab rusaknya

Inc., 2003); Riyawati, 2006). Riyawati, D. Y. Perbedaan Kematangan Emosi pada Wanita Usia 25-35 Tahun Ditinjau dari Tingkat Pendidikan dan Usia Memasuki Perkawinan. (Fakultas Ilmu Pendidikan, Universitas Negeri Semarang, 2006).

${ }^{16}$ Riyawati, Ibid.

17 Riyawati, Ibid.

18 Patrick, S., Sells, J. N., Giordano, F. G., \& Tollerud, T. R. Intimacy, Differentiation, and Personality Variables as Predictors of Marital Satisfaction.

${ }^{19}$ Liddle, H. A., Santisteban, D. A., Levant, R. F., \& Bray, J. H. Family Psychology; Science-Based Interventions. (Washington, DC: American Psychological Association, 2002); Knauth. D. G. Family Secrets: An Illustrative Clinical Case Study Guided by Bowen Family Systems Theory. (Journal of Family Nursing, Vol. 9, No. 3, 331-344. Sage Publications, 2003).

${ }^{20}$ Matsunaga, M. \& Imahori, T. D. Profiling Family Communication Standards : A U.S.-Japan Comparison. (Communication Research. Vol. 36, No. 1, 3-31. Sage Publications, 2009).

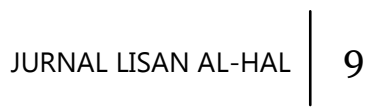


keharmonisan suatu hubungan dalam bangunan rumah tangga. Komunikasi yang tidak efektif sering menyebabkan timbulnya salah paham, salah persepsi, dan salah dalam mengambil keputusan. ${ }^{21}$

Komunikasi antara suami dan isteri harus terbuka, karena eksistensi suami-isteri dalam bangunan rumah tangga pada dasarnya merupakan suatu kesatuan. Komunikasi yang terbuka diharapkan dapat menghindari kesalahpamahan. Dalam batas-batas tertentu sifat keterbukaan dalam komunikasi juga dilaksanakan dengan anak-anak, apabila anak-anak telah dapat berpikir secara baik dan telah dapat mempertimbangkan secara baik mengenai hal-hal yang dihadapinya. ${ }^{22}$ Dengan demikian, komunikasi yang terbuka akan menimbulkan saling pengertian di antara seluruh anggota keluarga dan akan terbina serta tercipta tanggung jawab sebagai anggota keluarga. ${ }^{23}$

Menurut Walgito, di samping keterbukaan dalam komunikasi, komunikasi di dalam keluarga sebaiknya merupakan komunikasi dua arah, yaitu saling memberi dan saling menerima di antara anggota keluarga. Dengan komunikasi dua arah akan terdapat umpan balik, sehingga dengan demikian akan tercipta komunikasi hidup, komunikasi yang dinamis. Komunikasi dua arah akan menggiring masing-masing pihak aktif dan dapat bertukar pendapat mengenai masalah yang dikomunikasikan. ${ }^{24}$ Intensitas dan keterbukaan komunikasi dalam rumah tangga perlu diusahakan dan dibiasakan agar setiap anggota keluarga senantiasa mendapat dan memberikan berita-berita yang benar, sehingga implikasinya anak juga akan terbiasa berkomunikasi dengan baik dalam lingkungan keluarga maupun lingkungan sosial. ${ }^{25}$

${ }^{21}$ Ahira, A. Menghindari Perpecahan dan Menjaga Keharmonisan Keluarga.

${ }^{22}$ Schrodt, P., Ledbetter, A. M., Jernberg, K. A., Larson, L., Brown, N., \& Glonek, K. Family communication patterns as mediators of communication competence in the parentchild relationship. (Journal of Social and Personal Relationships. Vol. 26, No. 6-7, 853874. Sage Publications, 2009).

${ }^{23}$ Niska, K. J. Mexican American Family Survival, Continuity, and Growth: The Parental Perspective. (Nursing Science Quarterly, Vol. 14 No. 4, 322-329. Sage Publications, 2001).

${ }^{24}$ Walgito, Bimo. Bimbingan \& Konseling di Sekolah. (Yogyakarta: Andi Offset, 2004).

${ }^{25}$ Schrodt, P., Ledbetter, A. M., Jernberg, K. A., Larson, L., Brown, N., \& Glonek, K. Family communication patterns as mediators of communication competence in the parentchild relationship.

10 JURNAL LISAN AL-HAL 


\section{B. Kebahagiaan}

\section{Arti Kebahagiaan}

Kebahagian dalam pernikahan dapat di lihat dari kualitas pernikahan dan dilihat dari sejauh mana kesejahteraan psikologisnya dan perkawinan yang lebih lamalah yang bahagia, dalam artian bahwa jika sebuah rumah tangga tidak bisa mempertahankan hubungan pernikahan meraka, maka keluarga tersebut tidak dikatakan sebagai orang yang bahagia dalam pernikahanan. ${ }^{26}$ Dan juga pernikahan yang bisa dikatakan bahagia adalah sejauh mana tingkat kepuasan dalam pernikahan dan ketidakpuasan dalam pernikahan, Hawkins dan Booth menugtip pendapat Snyder dan Shane yang menyatakan bahwa pernikahan yang tidak bahagia adalah seseorang yang memiliki lebih dari satu isteri. ${ }^{27}$

Kebahagian dalam pernikahan ada orang yang menyatakan bahwa kebahagiaan dalam pernikahan adalah penilaian yang dibuat antara pasangan suami istri yang akan menghasilkan kearah well-being dan kepuasan dalam pernikahan. Dalam ikatan tali pernikahan banyak hal yang harus kita persiapkan utuk mencapai sebuah kebahagian dalam pernikahan, seperti halnya kesiapan mental dan juga materi, karena dengan mempersiapkan dua hal tersebtu paling tidak akan meringankan beban yang akan terjadi secara tidak diduga. ${ }^{28}$

Karena yang namanya sebuah keluarga tidak akan lepas dari yang namanya rintangan, sesuai dengan namanya "rumah tangga" jadi sebuah keluarga yang dibangun oleh pasangan suami istri diibaratkan kepada sebuah tangga, yang akan melalui beberapa tahapan, dan tahapan tersebut apabila pasangan suami istri sanggup melewatimnya dengan sabar dan tabah akan menghasilkan sebuah keluarga yang bahagia dan harmonis dan jika tidak bisa melewatinya dengan sabar dan tabah maka yang akan terjadi sebaliknya. ${ }^{29}$

\section{Ciri-Ciri Keluarga Bahagia}

Sebuah keluarga akan mendapatkan kebahagiaan jika hubungan dalam kehidupan rumah tangga selalu diwarnai oleh cara-cara

26 Snyder, C.R. \& Shane, J. L. Positive Psychology The Scientific And Practical Exploration Of Human Strengths.

${ }^{27}$ Snyder, C.R. \& Shane, J. L. Ibid.

28 DeMaris, A., Mahoney, A., \& Pargament, K. I. Sanctification of Marriage and General Religiousness as Buffers of the Effects of Marital Inequity. (Journal of Family Issues. Vol. 31, No. 10, 1255-1278. Sage Publications, 2010).

${ }^{29}$ DeMaris, dkk., Ibid.

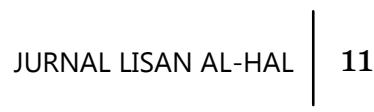


berinterkasi dan kondisi ${ }^{30}$ :

a. Menunjukkan sikap yang hangat dan kepercayaan dalam interaksi keluarga

b. Mempunyai sifat saling terbuka dan menghargai dalam interaksi dan mampu bicara jujur serta menyampaikan ketidaksetujuan tanpa adanya rasa takut

c. Mempunyai kemampuan untuk mendiskusikan dan memfokuskan pada hal-hal yang menjadi perhatian, sementara perhatiannya sekarang, bukan kejadian-kejadian yang lampau atau pada kekecewaankekecewaan.

d. Saling berbagi pandangan mengenai realitas di dalam keluarga

e. Menggunakan cara negosiasi daripada kekuasaan dalam memecahkan masalah

f. Meningkatkan struktur keluarga yang fleksibel dengan distribusi tanggung jawab dan hak-hak yang sesuai antara anak-anak dengan orang tua

g. Menunjukkan inisiatif personal yang tinggi dan meminta tanggung jawab personal bagi pemilihan dan perhatiannya, juga bagi masalahmasalah yang berhubungan dengan disabilitas, kesehatan mental atau perubahan karir

h. Mempunyai kemampuan untuk menyesuaikan pada perubahan, mempertahankan keseimbangan kohesi, adaptabilitas dan komunikasi walupun tidak berarti keluarga yang sehat selalu dalam kondisi seimbang. ${ }^{31}$

\section{Keharmonisan Keluarga}

Keluarga merupakan satu organisasi sosial yang paling penting dalam kelompok sosial dan keluarga merupakan lembaga di dalam masyarakat yang paling utama bertanggung jawab untuk menjamin kesejahteraan sosial dan kelestarian biologis anak manusia. ${ }^{32}$ Sedangkan keharmonisan keluarga itu akan terwujud apabila masing-masing unsur dalam keluarga itu dapat berfungsi dan berperan sebagimana mestinya ${ }^{33}$ dan tetap berpegang teguh pada nilai- nilai agama, maka interaksi sosial yang harmonis antar unsur dalam keluarga itu akan dapat diciptakan.

${ }^{30}$ Carroll, J. S., Badger, S., \& Yang, C. The Ability to Negotiate or the Ability to Love? : Evaluating the Developmental Domains of Marital Competence.

${ }^{31}$ Crisp, R. J. \& Turner R. N. Essential Social Psychology.; Carroll, dkk., Ibid.

32 Thomas, M. \& Bailey, N. Out of Time: Work, Temporal Synchrony and Families. (Sociology. BSA Publications Ltd. Vol. 43, No. 4, 613-630. Sage Publications, 2009).

${ }^{33}$ Kidman, A. Family Life; Adapting to Change A self Help Manual.

12 JURNAL LISAN AL-HAL 
Dalam kehidupan berkeluarga antara suami isteri dituntut adanya hubungan yang baik dalam arti diperlukan suasana yang harmonis yaitu dengan menciptakan saling pengertian, saling terbuka, saling menjaga, saling menghargai dan saling memenuhi kebutuhan. ${ }^{34}$ Setiap orangtua bertanggung jawab juga memikirkan dan mengusahakan agar senantiasa terciptakan dan terpelihara suatu hubungan antara orangtua dengan anak yang baik, efektif dan menambah kebaikan dan keharmonisan hidup dalam keluarga, sebab telah menjadi bahan kesadaran para orangtua bahwa hanya dengan hubungan yang baik kegiatan pendidikan dapat dilaksanakan dengan efektif dan dapat menunjang terciptanya kehidupan keluarga yang harmonis. ${ }^{35}$

Anak yang hubungan perkawinan orang tuanya bahagia akan mempersepsikan rumah mereka sebagai tempat yang membahagiakan untuk hidup karena makin sedikit masalah antar orangtua, semakin sedikit masalah yang dihadapi anak, dan sebaliknya hubungan keluarga yang buruk akan berpengaruh kepada seluruh anggota keluarga. Suasana keluarga ynag tercipta adalah tidak menyenangkan, sehingga anak ingin keluar dari rumah sesering mungkin karena secara emosional suasana tersebut akan mempengaruhi masing-masing anggota keluarga untuk bertengkar dengan lainnya. ${ }^{36}$

Mengacu pada beberapa pendapat di atas dapat disimpulkan persepsi keharmonisan keluarga adalah persepsi terhadap situasi dan kondisi dalam keluarga dimana di dalamnya tercipta kehidupan beragama yang kuat, suasana yang hangat, saling menghargai, saling pengertian, saling terbuka, saling menjaga dan diwarnai kasih sayang dan rasa saling percaya sehingga memungkinkan anak untuk tumbuh dan berkembang secara seimbang. ${ }^{37}$

${ }^{34}$ Patrick, S., Sells, J. N., Giordano, F. G., \& Tollerud, T. R. Intimacy, Differentiation, and Personality Variables as Predictors of Marital Satisfaction.

${ }^{35}$ Crittenden P. M. \& Dallos, R. All in the Family: Integrating Attachment and Family Systems Theories.

${ }^{36}$ Crittenden P. M. \& Dallos, R. Ibid.

${ }^{77}$ Martyn, K. K., Cherry, C. J. L., Villarruel, A. M., Cabriales, E. G., Zhou, Y., Ronis, D. L., \& Eakin, B. Mexican Adolescents' Alcohol Use, Family Intimacy, and Parent-Adolescent Communication. (Journal of Family Nursing. Vol. 15, No. 2, 152-170. Sage Publications, 2009). 


\section{a. Aspek-Aspek Keharmonisan Keluarga}

Lodro $^{38}$ mengemukakan enam aspek sebagai suatu pegangan hubungan perkawinan bahagia adalah:

1) Menciptakan kehidupan beragama dalam keluarga.

Sebuah keluarga yang harmonis ditandai dengan terciptanya kehidupan beragama dalam rumah tersebut. Hal ini penting karena dalam agama terdapat nilai-nilai moral dan etika kehidupan. Berdasarkan beberapa penelitian ditemukan bahwa keluarga yang tidak religius yang penanaman komitmennya rendah atau tanpa nilai agama sama sekali cenderung terjadi pertentangan konflik dan percekcokan dalam keluarga. ${ }^{39}$

2) Mempunyai waktu bersama keluarga

Keluarga yang harmonis selalu menyediakan waktu untuk bersama keluarganya, baik itu hanya sekedar berkumpul, makan bersama, menemani anak bermain dan mendengarkan masalah dan keluhankeluhan anak, dalam kebersamaan ini anak akan merasa dirinya dibutuhkan dan diperhatikan oleh orangtuanya, sehingga anak akan betah tinggal di rumah. ${ }^{40}$

3) Mempunyai komunikasi yang baik antar anggota keluarga

Komunikasi merupakan dasar bagi terciptanya keharmonisan dalam keluarga. Remaja akan merasa aman apabila orangtuanya tampak rukun, karena kerukunan tersebut akan memberikan rasa aman dan ketenangan bagi anak, komunikasi yang baik dalam keluarga juga akan dapat membantu remaja untuk memecahkan permasalahan yang dihadapinya di luar rumah, dalam hal ini selain berperan sebagai orangtua, ibu dan ayah juga harus berperan sebagai teman, agar anak lebih leluasa dan terbuka dalam menyampaikan semua permasalahannya. ${ }^{41}$

4) Saling menghargai antar sesama anggota keluarga

Keluarga yang harmonis adalah keluarga yang memberikan tempat bagi setiap anggota keluarga menghargai perubahan yang terjadi dan

38 Lodro, W. Keharmonisan Keluarga Dengan Perkawinan Bahagia. http://www.kainsutera.com/ info-remaja/keharmonisan-keluarga-dengan-perkawinanbahagia.html, 2010).

39 DeMaris, A., Mahoney, A., \& Pargament, K. I. Sanctification of Marriage and General Religiousness as Buffers of the Effects of Marital Inequity.

${ }^{40}$ Martyn, K. K., Cherry, C. J. L., Villarruel, A. M., Cabriales, E. G., Zhou, Y., Ronis, D. L., \& Eakin, B. Mexican Adolescents' Alcohol Use, Family Intimacy, and Parent-Adolescent Communication.; Patrick, S., Sells, J. N., Giordano, F. G., \& Tollerud, T. R. Intimacy, Differentiation, and Personality Variables as Predictors of Marital Satisfaction.

${ }^{41}$ Martyn, dkk., Ibid.

14 JURNAL LISAN AL-HAL 
mengajarkan keterampilan berinteraksi sedini mungkin pada anak dengan lingkungan yang lebih luas. ${ }^{42}$

5) Kualitas dan kuantitas konflik yang minim.

Faktor lain yang tidak kalah pentingnya dalam menciptakan keharmonisan keluarga adalah kualitas dan kuantitas konflik yang minim, jika dalam keluarga sering terjadi perselisihan dan pertengkaran maka suasana dalam keluarga tidak lagi menyenangkan. Dalam keluarga harmonis setiap anggota keluarga berusaha menyelesaikan masalah dengan kepala dingin dan mencari penyelesaian terbaik dari setiap permasalahan. ${ }^{43}$

6) Adanya hubungan atau ikatan yang erat antar anggota keluarga.

Hubungan yang erat antar anggota keluarga juga menentukan harmonisnya sebuah keluarga, apabila dalam suatu keluarga tidak memiliki hubungan yang erat maka antar anggota keluarga tidak ada lagi rasa saling memiliki dan rasa kebersamaan akan kurang. Hubungan yang erat antar anggota keluarga ini dapat diwujudkan dengan adanya kebersamaan, komunikasi yang baik antar anggota keluarga dan saling menghargai. ${ }^{44}$

Keenam aspek tersebut mempunyai hubungan yang erat satu dengan yang lainnya. Proses tumbuh kembang anak sangat ditentukan dari berfungsi tidaknya keenam aspek di atas, ${ }^{45}$ untuk menciptakan keluarga harmonis peran dan fungsi orangtua sangat menentukan, ${ }^{46}$ sedangkan keluarga yang tidak bahagia atau tidak harmonis akan mengakibatkan persentase anak menjadi nakal semakin tinggi. ${ }^{47}$

\footnotetext{
42 Patrick, S., Sells, J. N., Giordano, F. G., \& Tollerud, T. R. Intimacy, Differentiation, and Personality Variables as Predictors of Marital Satisfaction.

${ }^{43}$ Crittenden, P. M. \& Dallos, R. All in the Family: Integrating Attachment and Family Systems Theories.

${ }^{44}$ Crittenden \& Dallos, Ibid.; Patrick, , S., Sells, J. N., Giordano, F. G., \& Tollerud, T. R. Intimacy, Differentiation, and Personality Variables as Predictors of Marital Satisfaction.; Martyn, K. K., Cherry, C. J. L., Villarruel, A. M., Cabriales, E. G., Zhou, Y., Ronis, D. L., \& Eakin, B. Mexican Adolescents' Alcohol Use, Family Intimacy, and Parent-Adolescent Communication.

45 Lodro, W. Keharmonisan Keluarga Dengan Perkawinan Bahagia. http://www.kainsutera.com/ info-remaja/keharmonisan-keluarga-dengan-perkawinanbahagia.html

${ }^{46}$ Kidman, A. Family Life; Adapting to Change A self Help Manual.

${ }^{47}$ Martyn, K. K., Cherry, C. J. L., Villarruel, A. M., Cabriales, E. G., Zhou, Y., Ronis, D. L., \& Eakin, B. Mexican Adolescents' Alcohol Use, Family Intimacy, and Parent-Adolescent Communication.
} 


\section{b. Faktor-Faktor yang Mempengaruhi Keharmonisan Keluarga}

Pertama, Komunikasi interpersonal. Komunikasi interpersonal merupakan faktor yang sangat mempengaruhi keharmonisan keluarga, karena komunikasi akan menjadikan seseorang mampu mengemukakan pendapat dan pandangannya, sehingga mudah untuk memahami orang lain dan sebaliknya tanpa adanya komunikasi kemungkinan besar dapat menyebabkan terjadinya kesalahpahaman yang memicu terjadinya konflik. ${ }^{48}$

Kedua, Tingkat ekonomi keluarga. Menurut beberapa penelitian, tingkat ekonomi keluarga juga merupakan salah satu faktor yang menentukan keharmonisan keluarga. Semakin tinggi sumber ekonomi keluarga akan mendukung tingginya stabilitas dan kebahagian keluarga, tetapi tidak berarti rendahnya tingkat ekonomi keluarga merupakan indikasi tidak bahagianya keluarga. Tingkat ekonomi hanya berpengaruh trerhadap kebahagian keluarga apabila berada pada taraf yang sangat rendah sehingga kebutuhan dasar saja tidak terpenuhi dan inilah nantinya yang akan menimbulkan konflik dalam keluarga. ${ }^{49}$

Ketiga, Sikap orang tua. Sikap orang tua juga berpengaruh terhadap keharmonisan keluarga terutama hubungan orangtua dengan anakanaknya. Orang tua dengan sikap yang otoriter akan membuat suasana dalam keluarga menjadi tegang dan anak merasa tertekan, anak tidak diberi kebebasan untuk mengeluarkan pendapatnya, semua keputusan ada ditangan orang tuanya sehingga membuat remaja itu merasa tidak mempunyai peran dan merasa kurang dihargai dan kurang kasih sayang serta memandang orang tuanya tidak bijaksana. Orang tua yang permisif cenderung mendidik anak terlalu bebas dan tidak terkontrol karena apa yang dilakukan anak tidak pernah mendapat bimbingan dari orang tua. Kedua sikap tersebut cenderung memberikan peluang yang besar untuk menjadikan anak berperilaku menyimpang, sedangkan orang tua yang bersikap demokratis dapat menjadi pendorong perkembangan anak kearah yang lebih positif. ${ }^{50}$

${ }^{48}$ Schrodt, P., Ledbetter, A. M., Jernberg, K. A., Larson, L., Brown, N., \& Glonek, K. Family communication patterns as mediators of communication competence in the parentchild relationship.

${ }^{49}$ Mandara, J. \& Murray, C. B. Effects of Parental Marital Status, Income, and Family Functioning on African American Adolescent Self-Esteem. (Journal of Family Psychology. Vol. 14, No. 3, 475-490. American Psychological Association, Inc., 2000).

${ }^{50}$ Martyn, K. K., Cherry, C. J. L., Villarruel, A. M., Cabriales, E. G., Zhou, Y., Ronis, D. L., \& Eakin, B. Mexican Adolescents' Alcohol Use, Family Intimacy, and Parent-Adolescent Communication.; Schrodt, P., Ledbetter, A. M., Jernberg, K. A., Larson, L., Brown, N., \& 
Keempat, Ukuran keluarga. Jumlah anak dalam satu keluarga sangat menentukan cara orang tua mengontrol perilaku anak, menetapkan aturan, mengasuh dan perlakuan efektif orang tua terhadap anak. Keluarga yang lebih kecil mempunyai kemungkinan lebih besar untuk memperlakukan anaknya secara demokratis dan lebih baik untuk kelekatan anak dengan orang tua. ${ }^{51}$

\section{Cinta}

\section{Arti Cinta}

Menurut Sternberg, 52 cinta adalah sebuah kisah yang ditulis oleh setiap orang. Kisah tersebut merefleksikan kepribadian, minat dan perasaan seseorang terhadap suatu hubungan. Kisah pada setiap orang berasal dari "skenario" yang sudah dikenalnya, apakah dari orang tua, pengalaman, cerita dan sebagainya. Kisah ini biasanya mempengaruhi orang bagaimana ia bersikap dan bertindak dalam sebuah hubungan.

Menurut Crisp and Turner, ${ }^{53}$ cinta adalah reaksi emosional yang sama dikenalnya dan sama mendasarnya dengan rasa marah, sedih, gembira dan rasa takut, cinta adalah sesuatu yang lebih dari sekedar pertemanan biasa dan melebihi rasa tertarik secara romantis dan seksual dengan seseorang. Percintaan adalah dengan menyadari bahwa percintaan dibangun sebagian berdasarkan khayalan dan ilusi positif. Sedangkan dalam Islam, perasaan cinta lebih dekat dengan kata iman yang mengungkapkan perasaan yang berhubungan dengan trust dan belive . Perasaan cinta hanya bisa dirasakan, seperti halnya ketika manusia mempunya perasaan cinta, maka ketika disebut nama orang yang dia sukai akan gemetar hatinya. Sedangkan, ketika orang yang dicintai tersebut berbicara, maka orang tersebut bertambah semakin cinta. ${ }^{54}$

Sternberg terkenal dengan teorinya tentang Triangular Theory of Love (Teori Segitiga Cinta). Segitiga cinta itu mengandung komponen: (1) keintiman (intimacy), (2) gairah (passion) dan (3) komitmen (commitment). Keintiman adalah elemen emosi, yang di dalamnya terdapat kehangatan, kepercayaan (trust) dan keinginan untuk membina

Glonek, K. Family communication patterns as mediators of communication competence in the parent-child relationship.; Crittenden, P. M. \& Dallos, R. All in the Family: Integrating Attachment and Family Systems Theories.

${ }^{51}$ Crittenden, P. M. \& Dallos, R. Ibid.

52 Sternberg, R. J. A Triangular Theory of Love.

${ }^{53}$ Crisp R. J. \& Turner R. N. Essential Social Psychology.

${ }^{54}$ Aron, A. \& Henkemeyer, L. Marital Satisfaction and Passionate Love. 
hubungan. Ciri-cirinya antara lain; individu akan merasa dekat dengan individu lain, senang bercakap-cakap dengan individu lain tersebut sampai waktu yang lama, merasa rindu bila lama tidak bertemu, dan ada keinginan untuk bergandengan tangan atau saling merangkul bahu. ${ }^{55}$

Gairah adalah elemen motivasional yang didasari oleh dorongan dari dalam diri yang bersifat seksual. ${ }^{56}$ Komitmen adalah elemen kognitif, berupa keputusan secara berkesinambungan untuk tetap menjalankan suatu kehidupan bersama. Menurut Sternberg, setiap komponen tersebut, pada setiap individu berbeda derajatnya. Ada yang hanya tinggi di gairah, tetapi rendah pada komitmen. Sedangkan, cinta yang ideal adalah apabila ketiga komponen itu berada dalam proporsi yang sesuai pada suatu waktu tertentu. ${ }^{57}$ Misalnya, pada tahap awal hubungan yang paling besar adalah komponen keintiman, kemudian berlanjut pada gairah yang lebih besar (dalam beberapa budaya) dan disertai dengan komitmen yang lebih besar dalam bentuk perkawinan. ${ }^{58}$

Ketiga komponen cinta di atas, dapat membentuk atau melahirkan delapan kombinasi jenis cinta. Delapan kombinasi tersebut adalah : (1) nonlove, tak ada gairah yang timbul, biasanya hubungan dengan individu dalam lingkungan sehari-hari karena interaksinya hanya bersifat sepintas saja, tidak memiliki komponen gairah, keintiman dan komitmen; (2) liking (persahabatan), sebagai salah satu komponen emosi yang ada adalah perasaan suka bukanlah cinta, hanya memiliki komponen keintiman; (3) infatuation love (ketergila-gilaan), gairah yang timbul tanpa keintiman dan komitmen, biasanya cinta yang terjadi pada pandangan pertama; (4) empty love (cinta kosong), ada unsur komitmen tetapi kurang intim dan kurang gairah. Hubungan yang lama akan semakin membosankan; (5) romantic love (cinta romantis), hubungan intim yang menggairahkan tetapi kurang komitmen sehingga pasangan yang jatuh cinta romantis ini terbawa secara fisik dan emosi, tetapi tidak mengharapkan hubungan jangka panjang; (6) companionate love, hasil dari komponen keintiman dan komitmen tanpa adanya gairah cinta. Dalam perkawinan yang lama tidak akan menggairahkan secara fisik lagi; (7) fatous love (cinta buta), mempunyai gairah dan komitmen tetapi kurang intim, dimana cinta ini

${ }^{55}$ Sternberg, R. J. A Triangular Theory of Love.

56 Aron, A. \& Henkemeyer, L. Marital Satisfaction and Passionate Love. (Journal of Social and Personal Relationships. Vol. 12, No. 1, 139-146. Sage Publications, 1995).

${ }^{57}$ Sternberg, R. J. A Triangular Theory of Love.

${ }^{58}$ Lucas, T., Parkhill, M. R., Wendorf, C. A., Imamoglu, E. O., Weisfeld, C. C., Weisfeld, G. E., \& Shen, J. Cultural and Evolutionary Components of Marital Satisfaction : A Multidimensional Assessment of Measurement Invariance. 
sulit dipertahankan karena kurang adanya aspek emosi; (8) consummate love (cinta yang sempurna), yaitu cinta yang tersusun atas komponen keintiman, gairah dan komitmen. ${ }^{59}$ Cinta yang ideal adalah cinta yang memiliki komponen keintiman, gairah, dan komitmen yang seimbang. ${ }^{60}$

\section{Jenis-Jenis Cinta}

Crisp dan Turner dengan mengutip pendapat Lee, 61 mengemukakan tentang tipe cinta yang mempunyai pola yang berbeda dalam memanifestasikan cinta itu sendiri. Lee membuat tiga tipe utama dalam cinta : eros (passionate love), ludus (game playing role), and storge (friendship love). Tipe tadi bisa dikombinasikan dengan 3 tipe tambahan dari cinta : pragma (pragmatic love), dengan mengkombinasikan persahabatan dan element bermain-main, mania (possesive love) mengkobinasikan cinta membara dan bermain-main/ cinta yang tidak serius, dan agape (altruistic love) dengan mengkombinasikan cinta yang membara dengan persahabatan. Dia berpendapat bawa tipe cinta itu tidak dipengaruhi oleh perbedaan individu dan bisa timbul untuk semua orang. ${ }^{62}$ Berikut dua dorongan dari tipe cinta yaitu passionate love dan companionate love

\section{a. Passionate Love}

Passionate love (cinta membara) adalah pernyataan perasaan rindu akan orang lain yang berpengalaman adalah pengalaman tahap awal dalam satu hubungan romantis. Pada umumnya hal ini melibatkan emosi yang sangat kuat, secara terus-menerus berpikir tentang kekasih, dan ingin menghabiskan sebanyak mungkin waktu dengan mereka, bahkan dengan mengesampingkan teman-teman lain. Suatu respon yang intensif dan sering kali tidak realistik terhadap orang lain. Neuropsychologists telah menemukan bahwa pengalaman subjektif kecintaan dikaitkan dengan perubahan dalam kimiawi otak, khususnya peningkatan dopamin stimulan yang kuat, yang mengakibatkan rasa fisiologis. "Mereka juga membuktikan bahwa orang-orang yang jatuh cinta ketika otak mereka diberikan scan menunjukkan peningkatan aktivitas di nucleus caudatus (area dekat pusat otak) ketika mereka ditunjukkan foto-foto pasangan

${ }^{59}$ Crisp R. J. \& Turner R. N. Essential Social Psychology, London: Sage Publications, 2007); Carroll, J. S., Badger, S., \& Yang, C. The Ability to Negotiate or the Ability to Love? : Evaluating the Developmental Domains of Marital Competence.

${ }^{60}$ Aron, A. \& Henkemeyer, L. Marital Satisfaction and Passionate Love.

${ }^{61}$ Crisp R. J. \& Turner R. N. Essential Social Psychology.

${ }^{62}$ Crisp R. J. \& Turner R. N. Ibid. 
mereka, tetapi tidak ketika mereka ditunjukkan foto-foto teman-teman mereka. ${ }^{63}$

Ini daerah otak primitif mengarahkan gerakan-gerakan tubuh dan juga berhubungan dengan pahala dan kesenangan. Orang-orang dalam pengalaman ketika jatuh cinta terdapat berbagai pengalaman positif, termasuk peningkatan efektivitas diri dan harga diri. Oleh karena itu kecintaan dikaitkan dengan beberapa kualitatif neurofisiologis dan psikologis bagi beberapa negara yang berbeda. 64

Hatfield and Walster berpendapat bahwa kecintaan akan muncul ketika tiga kondisi terpenuhi. Pertama, adalah penting bagi seorang individu untuk memahami apa itu cinta dan memiliki harapan bahwa pada suatu saat mereka akan jatuh cinta. Dengan kata lain, apakah seseorang jatuh cinta tergantung pada apakah mereka berasal dari budaya yang percaya pada konsep cinta. Hal ini terjadi dalam kebudayaan Barat, seperti Inggris dan Amerika Serikat, tetapi cinta dianggap kurang penting dalam beberapa budaya Timur, di mana perjodohan adalah norma. Kedua, perlu untuk bertemu seseorang yang sesuai dengan harapan atau dengan kata lain bisa bertemu dengan pasangan yang tepat, misalnya, seseorang yang menarik dan lebih memprioritaskan seks. Ketiga, ketika berpikir bahwa di hadapan mereka ada seseorang mitra yang memiliki potensi, maka orang tersebut mengalami keadaan fisiologis yang kemudian mereka sebut dengan atribut kekasih. ${ }^{65}$

Mengenai faktor fisiologis dapat menimbulkan perasaan jatuh cinta, Hatfield mengambil teori dari Walster Schachter dan Singer's tentang dua-teori faktor emosi dan mengusulkan sebuah teori tiga faktor cinta. ${ }^{66}$ Teori ini berpendapat bahwa ada tiga kondisi yang harus dipenuhi untuk jatuh cinta: (1) pertemuan yang cocok dengan seorang kekasih yang potensial, (2) menghubungkan rangsangan fisiologis yang potensial dengan kehadiran kekasih, dan (3) memahami dan menerima konsep cinta. Sedangkan teori Singer Schachter lebih memfokuskan secara khusus pada peran nafsu dalam cinta romantis, dan menyoroti kebutuhan untuk mengenali konsep cinta. Peneliti menyelami rangsangan fisiologis dalam berbagai konteks, misalnya saat bertengkar dengan seseorang,

${ }^{63}$ Fisher, H. Why We Love: The Nature and Chemistryof Romantic. (New York: Holt, 2004); Aron, A. \& Henkemeyer, L. Marital Satisfaction and Passionate Love.

64 Aron, A., Paris, M., \& Aron, E. N. Falling and Love Prospective Studies of Self Concept Change. Journal of Personality and Social Pasychology, 69, 1102-1112, 1995); Aron, A. \& Henkemeyer, L. Marital Satisfaction and Passionate Love..

65 Aron, A. \& Henkemeyer, L. Ibid.

${ }^{66}$ Crisp R. J. \& Turner R. N. Essential Social Psychology.

20 JURNAL LISAN AL-HAL 
ketika berjalan di daerah yang tidak aman, atau ketika menerima nilai tertinggi dalam ujian. Reaksi fisiologis yang dimiliki setiap individu pada situasi yang berbeda cenderung mirip, tetapi tetap terdapat predikat yang berbeda untuk setiap reaksi fisiologis tersebut: kemarahan selama pertengkaran, rasa takut atau kecemasan ketika individu merasa tidak aman, dan kegembiraan ketika individu mencapai sesuatu yang berharga.

Schachter dan Singer menjelaskan bahwa ketika peristiwa menimbulkan rangsangan fisiologis internal, seseorang mencari isyaratisyarat eksternal untuk menentukan alasan rangsangan ini. Ketika gairah terjadi selama interaksi dengan anggota berdasarkan seksual, mungkin hal ini ditafsirkan sebagai romantis dan ketertarikan seksual. Jika teori ini benar, rangsangan dari sumber lain mungkin bisa salah ditafsirkan sebagai aroma romantis di hadapan orang yang menarik. Crisp dan Turner mengutip pendapat Zillman, ${ }^{67}$ menggambarkan proses psikologis ini sebagai gairah yang disebabkan oleh salah satu stimulus yang ditransfer dan ditambahkan untuk menimbulkan gairah oleh rangsangan kedua yang disebut dengan eksitasi transfer. Seperti yang terjadi pada ketertarikan dan pertemanan, ketertarikan romantis dipengaruhi oleh faktor-faktor seperti kedekatan fisik, penampilan, dan kesamaan. Sebagai tambahan, percintaan meliputi ketertarikan seksual, keinginan akan adanya penerimaan total oleh orang lain, dan beberapa khayalan yang didasarkan pada ilusi yang positif. ${ }^{68}$

\section{b. Companionate Love}

Cinta karib (persahabatan) perasaan sayang yang dirasakan dengan seseorang yang ada di sekeliling secara mendalam dan bisa terapkan kepada teman atau juga pada teman yang romantis. Cinta meliputi bermacam-macam kemungkinan; contohnya adalah cinta membara, dan cinta karib. Cinta membara adalah respon emosional yang tiba-tiba dan berlebihan. Sedangkan Cinta karib, sebaliknya lebih seperti persahabatan yang meliputi kepedulian, rasa saling suka, dan penghargaan. Selain cinta membara dan cinta karib, Hendrick menambahkan empat jenis cinta lainnya dan Sternberg mengkonseptualisasikan cinta dalam bentuk segitiga, dengan tiga sudutnya melambangkan cinta karib, cinta membara, dan keputusan/komitmen. ${ }^{69}$

${ }^{67}$ Crisp R. J. \& Turner R. N. Ibid.

${ }^{68}$ Crisp R. J. \& Turner R. N. Ibid.

${ }^{69}$ Crisp R. J. \& Turner R. N. Ibid. 
Social psychologists have defined love in a number of differentPsikolog sosial telah mendefinisikan cinta dalam sejumlah cara yang berbeda. Menurut Lee tipologi cinta, ada tiga jenis cinta primer (bersemangat, permainan-permainan, dan persahabatan cinta) yang dapat dikombinasikan dengan cara yang berbeda untuk membentuk tiga jenis cinta sekunder (pragmatis, posesif, dan altruistik cinta), yang gabungan bergairah dan permainan-bermain cinta, dan agape (cinta altruistik), yang menggabungkan gairah dan persahabatan. Lee berpendapat bahwa jenis cinta berpengalaman tidak dipengaruhi oleh perbedaan individu dan dapat muncul untuk setiap orang. Atau, Sternberg mengusulkan teori segitiga cinta, dengan mengatakan bahwa cinta dapat diklasifikasikan secara berbeda tergantung pada tingkat gairah, keintiman dan komitmen. Penelitian dalam teori ini telah menemukan bukti yang jelas untuk dua jenis cinta: gairah cinta dan companionate cinta. Gairah cinta adalah suatu keadaan yang intens kerinduan untuk orang lain yang berpengalaman di awal hubungan romantis dan berhubungan dengan perubahan kimia otak dan peningkatan aktivitas di nucleus caudatus wilayah otak, daerah juga terkait dengan pahala dan kesenangan. Menurut teori tiga faktor cinta, perasaan cinta akan muncul ketika (1) seorang individu percaya pada konsep cinta, (2) bertemu dengan seseorang yang sesuai dengan harapan mereka mitra yang tepat, dan (3) pengalaman keadaan fisiologis gairah ketika di hadapan orang itu, yang kemudian dikaitkan dengan kehadiran orang tersebut dan diberi label ketertarikan romantis. Pada kesempatan itu, fisiologis dari sumber yang berbeda secara tidak sengaja dapat ditafsirkan sebagai atraksi romantis di hadapan orang yang menarik, digambarkan sebagai sebuah proses transfer eksitasi. ${ }^{70}$

Passionate love is relatively short-live Passionate cinta adalah hidup yang relatif pendek. Jika sebuah hubungan berlangsung di luar tahap ini, perasaan akan diganti dengan yang kurang bersemangat tetapi lebih cinta abadi, companionate cinta. Menurut psikolog evolusioner, sistem perkawinan seksual menjelaskan tahap awal suatu hubungan, tetapi dalam tahap-tahap selanjutnya, sistem lampiran lebih penting; orangtua yang melekat satu sama lain lebih cenderung untuk tinggal bersama-sama untuk membesarkan anak-anak mereka, meningkatkan keturunan, serta kemungkinan untuk bertahan hidup sampai dewasa. ${ }^{71}$

${ }^{70}$ Crisp R. J. \& Turner R. N. Ibid.

${ }^{71}$ Crisp R. J. \& Turner R. N. Ibid.

22 JURNAL LISAN AL-HAL 


\section{Makna Cinta dalam Keluarga}

Proses terjadinya dating sebelum membentuk sebuah keluarga biasanya orang lebih banyak menggunakan istilah pacaran. Adapun istilah pacaran sebenarnya berasal dari sebuah budaya di masyarakat yang merupakan proses seseorang menuju pernikahan. ${ }^{72}$ Pada tahun sekitar 1950 di Amerika Serikat dalam memilih pasangan hidup mengalami sebuah transisi. Padahal jauh sebelum nilai-nilai agama lebih umum dilakukan oleh masyarakat melalui pacaran yang lebih reflektif. Mereka lebih ketat mengawasi anak-anak muda ketika melakukan proses kencan kepada pasangannya. Hal itu bisa tercermin dari bentuk arsitek bangunan rumahnya sekitar tahun 1930-an. Tidak jauh berbeda dengan budaya di Indonesia khususnya di daerah jawa yang mengadopsi pacaran dari seuah simbol "bunga pacar". Dalam pencermatan dari pemakalah ini berdasarkan cerita dari orang tua (nenek) bahwa sebelum orang jawa mengalami proses pernikahan mempunyai kebiasaan memingit calon pengantin putri dengan cara memberi tanda pada kuku jari tangannya dengan bunga pacar. Gadis pingitan tersebut mempunyai maksud selama warna bunga pacar itu masih menempel pada kuku jarinya belum boleh ketemu dengan calon mempelai laki-laki. Proses tersebut memakan waktu kurang lebih 1 bulan sehingga kedua mempelai tersebut melangsungkan dalam sebuah pernikahan.

Pada dasarnya tujuan yang paling utama dalam sebuah pernikahan adalah memperoleh predikat keluarga yang harmonis, sakinah, mawaddah, wa rahmah. Untuk memperoleh predikat tersebut tentunya harus memadukan antara ketiga komponen dalam cinta yang telah tersebut di atas yaitu ; intimasi, gairah dan komitmen. Ketiga komponen dalam cinta tersebut adalah kondisi yang ideal yang menjadi tujuan seseorang melangsungkan sebuah prosesi pernikahan. ${ }^{73}$

\section{Kematangan Emosional}

Kematangan emosional dapat dipahami dengan mengetahui pengertian emosi dan kematangan terlebih dahulu, kemudian dijelaskan tentang kematangan emosi sebagai satu kesatuan. Istilah kematangan menunjukkan adanya kesiapan yang terbentuk dari pertumbuhan dan perkembangan pada diri individu. ${ }^{74}$

${ }^{72}$ Lucas, T., Parkhill, M. R., Wendorf, C. A., Imamoglu, E. O., Weisfeld, C. C., Weisfeld, G. E., \& Shen, J. Cultural and Evolutionary Components of Marital Satisfaction : A Multidimensional Assessment of Measurement Invariance.

${ }^{73}$ Crisp R. J. \& Turner R. N. Essential Social Psychology.

74 Hurlock, E. Psikologi Perkembangan. Suatu Pendekatan Sepanjang Rentang

$$
\begin{array}{l|l}
\text { JURNAL LISAN AL-HAL } & 23
\end{array}
$$


Hurlock menjelaskan bahwa kematangan emosi merupakan individu yang memiliki kontrol diri yang baik, mampu mengekspresikan emosinya dengan tepat atau sesuai dengan keadaan yang dihadapinya, sehingga lebih mampu beradaptasi karena dapat menerima beragam orang dan situasi dan memberikan reaksi yang tepat sesuai dengan tuntutan yang dihadapi. ${ }^{75}$ Sedangkan Yusuf mendifinisikan kematangan emosi sebagai kemampuan individu untuk dapat bersikap toleran, merasa nyaman, mempunyai kontrol diri sendiri, perasaan mau menerima dirinya dan orang lain, selain itu dapat menyatakan emosinya secara konstruktif dan kreatif. 76

\section{Kriteria Kematangan Emosional}

Pertama, Kemampuan untuk beradapatasi dengan realitas. Kemampuan yang berorientasi pada diri individu tanpa membentuk mekanisme pertahanan diri ketika konflik-konflik yang muncul mulai dirasakan menganggu perilakunya. Orang yang masak secara emosional melihat suatu akar permasalahan berdasarkan fakta dan kenyataan dilapangan, tidak menyalahkan orang lain atau hal-hal yang bersangkutan sebagai salah faktor penghambat. Ia dapat beradaptasi dengan lingkungannya dan selalu dapat berpikir positif terhadap masalah yang dihadapinya. ${ }^{77}$

Kedua, Kemampuan untuk beradaptasi dengan perubahaan. Perubahan mendadak kadang membuat seseorang menjadi menutup diri, menjaga jarak atau bahkan menghindari dari hal-hal yang berkisar lingkungan barunya. Kemasakan emosi menandakan bahwa seseorang dapat begitu cepat beradaptasi dengan hal-hal baru tanpa menjadikannya sebagai tekanan atau stresor. Kemampuan ini dapat tumbuh sebagai bentuk adaptasinya dengan lingkungan baru yang sengaja diciptakan untuk mengurangi stres yang dapat berkembang dalam dirinya. ${ }^{78}$

Ketiga, Dapat mengontrol gejala emosi yang mengarah pada kemunculan kecemasan. Munculnya kepanikan berawal dari

Kehidupan. (Terjemah). Edisi kelima. (Jakarta: Erlangga, 1994).

${ }^{75}$ Hurlock, E. Ibid.

${ }^{76}$ Syamsu Yusuf. Psikologi Perkembangan Anak dan Remaja. (Bandung: PT. Remaja Rosdakarya, 2004).

77 Huber, C. H., Navarro, R. L., Womble, M. W., \& Mumme, F. L. Family Resilience and Midlife Marital Satisfaction. The Family Journal: Counseling and Therapy for Couples and Families. Vol. 18, No. 2, 136-145. Sage Publications, 2010).

${ }^{78}$ Huber, dkk., Ibid.

$24 \mid$ JURNAL LISAN AL-HAL 
terkumpulnya simpton-simpton yang memberikan radar akan adanya bahaya dari luar. Penumpukan kadar rasa cemas berlebihan dapat memunculkan kepanikan yang luar biasa. Orang yang mempunyai kemasakan emosi dapat mengotrol gejala-gejala tersebut sebelum muncul kecemasan pada dirinya. ${ }^{79}$

Keempat, Kemampuan untuk menemukan kedamaian jiwa dari memberi dibandingkan dengan menerima. Semakin sehat tingkat kematangan emosi seseorang, individu tersebut dapat menangkap suatu keindahan dari memberi, ketulusan dalam membantu orang, membantu fakir miskin, keterlibatan dalam masalah sosial, keinginan unutk membantu orang lain, dan sebagainya. ${ }^{80}$

Kelima, Konsisten terhadap prinsip, janji, dan keinginan untuk menolong orang yang mengalami kesulitan. Orang yang matang secara emosi adalah orang-orang yang telah menemukan suatu prinsip yang kuat dalam hidupnya. Ia menghargai prinsip orang lain dan menghormati perbedaan-perbedaan yang ada. Ia selalu menepati janjinya dan selalu bertanggung jawab dengan apa yang telah di ucapkannya. Ia juga mempunyai keinginan untuk menolong orang lain yang mengalami kesulitan. 81

Keenam, Dapat meredam instink negatif menjadi energi kreatif dan konstruktif. Kematangan emosi yang dimiliki oleh individu akan dapat mengontrol perilaku-perilaku impulsif yang dapat merusak energi yang dimiliki oleh tubuh, individu dapat melakukan hal-hal yang bersifat positif dibandingkan memenuhi nafsu yang dapat merusak dan bersifat merusak. Ia mempunyai waktu yang lebih banyak untuk melakukan hal-hal yang lebih berguna untuk dirinya dan orang lain. ${ }^{82}$

Ketujuh, Kemampuan untuk mencintai. Cinta merupakan energi seseorang untuk bertahan dan menjadikannya lebih bergairah dalam menjalani hidup. ${ }^{83}$ Tidak hanya cinta antara sesama manusia, pengalaman spiritual, mencintai Tuhan pun merupakan keindahan bagi mereka yang yang merasakan keterdekatan dengan Sang Ilahi. ${ }^{84}$

${ }^{79}$ Huber, dkk., Ibid.

${ }^{80}$ Huber, dkk., Ibid.

${ }^{81}$ Crisp R. J. \& Turner R. N. Essential Social Psychology.

82 Knauth, D. G. Family Secrets: An Illustrative Clinical Case Study Guided by Bowen Family Systems Theory.

${ }^{83}$ Carroll, J. S., Badger, S., \& Yang, C. The Ability to Negotiate or the Ability to Love? : Evaluating the Developmental Domains of Marital Competence.

84 DeMaris, A., Mahoney, A., \& Pargament, K. I. Sanctification of Marriage and General Religiousness as Buffers of the Effects of Marital Inequity. 


\section{Faktor-Faktor yang mempengaruhi Kematangan Emosional}

Dalam proses pencapaiannya, kematangan emosional dipengaruhi oleh beberapa faktor. Berikut ini akan dikemukakan faktor-faktor yang berpengaruh terhadap pencapaian kematangan emosional sebagai berikut:

a. Faktor Fisik

Tingkat perkembangan emosi maupun intelegensi antara wanita yang belum mengalami menarche (pre-menarcheal girls) ada perbedaan. Wanita yang telah mengalami masa menarche memiliki tingkat perkembangan emosi maupun inteligensi yang lebih tinggi dibandingkan dengan wanita yang belum mengalami masa menarche. Hal tersebut diakibatkan karena terjadinya perubahan hormonal tubuh yang dimilikinya. ${ }^{85}$

Anak laki-laki yang terlambat masak secara fisik (physically retarded) ternyata menunjukkan kebutuhan akan social-acceptance dan agresivitas yang tinggi bila dibandingkan dengan anak laki-laki yang telah masak secara cepat, setelah subjek diperintahkan untuk merating dari sembilan jenis kebutuhan yang disediakan. Hal ini dikarenakan, anak lakilaki yang secara fisik terlambat masak memiliki rasa insecure dan dependence yang lebih besar. 86

b. Pola-pola Kontrol terhadap Emosi

Dalam mencapai kematangan emosi, terdapat pola-pola kontrol emosi yang ideal yang perlu dimiliki oleh individu, misalnya tidak melakukan represi-represi emosi yang tidak perlu dan mengendalikan emosi dengan wajar dan sesuai dengan harapan-harapan social. ${ }^{87}$

c. Intelegensi

Faktor-faktor intelegensi berpengaruh dalam persepsi diri, self evaluation, atau penilaian (appraisal) terhadap orang lain dan situasi lingkungan. Individu dengan inteligensi tinggi, kemungkinan akan memperoleh insight dalam pemecahan masalah emosianalnya secara lebih besar. ${ }^{88}$

d. Jenis Kelamin

85 Riyawati, D. Y. Perbedaan Kematangan Emosi pada Wanita Usia 25-35 Tahun Ditinjau dari Tingkat Pendidikan dan Usia Memasuki Perkawinan.

${ }^{86}$ Riyawati, Ibid.

${ }^{87}$ Jones, C. J. \& Meredith, W. Developmental Paths of Psychological Health From Early Adolescence to Later Adulthood. (Psychology and Aging. Vol. 15, No. 2, 351-360. American Psychological Association, Inc., 2000).

${ }^{88}$ Sternberg, R. J. What is the common thread of creativity? Its dialectical relation to intelligence and wisdom. (American Psychologist, 56, 360-362, 2001).

26 JURNAL LISAN AL-HAL 
Perbedaan hormonal maupun kondisi psikologis antara laki-laki dan wanita menyebabkan perbedaan karakteristik emosi di antara keduanya. Wanita mempunyai kematangan emosional, sikap hati-hati, dan sensitif serta kondisi yang tinggi daripada laki-laki. Oleh karena itu, lakilaki lebih tinggi dalam hal stabilitas emosi daripada wanita.

Wanita lebih bersifat emosional daripada laki-laki. Hal tersebut terjadi karena wanita memiliki kondisi emosi didasarkan peran sosial yang diberikan oleh masyarakat, yaitu wanita harus mengontrol perilaku agresif dan asertifnya, tidak seperti peran sosial laki-laki. Hal ini menyebabkan wanita kurang dapat mengontrol lingkungannya, yang pada akhirnya menimbulkan kecemasan-kecemasan. ${ }^{89}$

e. Usia

Kematangan emosional seseorang, perkembangannya seiring dengan pertambahan usia. Hal ini dikarenakan kematangan emosi dipengaruhi oleh tingkat pertumbuhan dan kemasakan fisik-fisiologis daripada seseorang. Sedangkan aspek fisik- fisiologis sudah dengan sendirinya ditentukan oleh faktor usia. Akan tetapi, tiap-tiap individu adalah berbeda (menurut pendekatan ideografi). ${ }^{90}$

\section{E. Intensitas Komunikasi}

Menurut Chaplin, intensitas yaitu kedalaman atau reaksi emosional dan kekuatan yang mendukung suatu pendapat atau sikap keluarga lainnya. ${ }^{91}$ Intensitas komunikasi dapat diukur dari apa-apa dan siapa yang saling dibicarakan, pikiran, perasaan, objek tertentu, orang lain atau dirinya sendiri. ${ }^{92}$ Intensitas komunikasi yang mendalam ditandai oleh kejujuran, keterbukaan, dan saling percaya, sehingga menimbulkan respon dalam bentuk perilaku atau tindakan..$^{93}$

\section{Fungsi Komunikasi dalam Keluarga}

Komunikasi merupakan salah satu faktor yang menentukan kebahagiaan manusia, komunikasi juga faktor paling penting untuk

${ }^{89}$ Hasanat, N. Apakah Perempuan lebih Depresif dari Laki-laki? (Laporan Penelitian tidak diterbitkan, Yogyakarta: Fakultas Psikologi UGM., 1994).

90 Riyawati, D. Y. Perbedaan Kematangan Emosi pada Wanita Usia 25-35 Tahun Ditinjau dari Tingkat Pendidikan dan Usia Memasuki Perkawinan.

${ }^{91}$ Chaplin, C.P. Kamus Lengkap Psikologi. Terjemah. (Jakarta: PT. Raja Grafindo Persada, 2000).

${ }^{92}$ Gunarsa, S.D dan Gunarsa, Y.S.D. Psikologi Praktis Anak, Remaja dan Keluarga. Cet. 7 (Jakarta: PT. BPK Gunung Mulia, 2004).

${ }_{93}$ Gunarsa, S.D dan Gunarsa, Y.S.D. Ibid. 
menjalin hubungan yang erat dengan seorang manusia lain. Ada beberapa fungsi komunikasi, ${ }^{94}$ di antaranya :

a. Membangun hubungan intim. Seorang individu memerlukan teman dekat untuk melakukan komunikasi dengannya supaya dapat menghilangkan rasa kesepian yang dialami jika individu tersebut dalam keadaan sendirian. Hal ini tidak bermakna bahwa apabila seorang individu itu sudak menikah tidak akan mengalami rasa kesepian. Kesepian dapat muncul kapan dan di mana saja, walaupun individu berada di dalam rumah sendiri dan dikelilingi oleh isteri atau suami atau anak anak. ${ }^{95}$

b. Komunikasi keluarga yang baik adalah memberi rangsangan. Sebagai manusia biasa, setiap individu memerlukan pasangan dalam hidup karena mereka memerlukan rangsangan, begitu juga anak-anak memerlukan ibu dan ayah sebagai rangsangan bagi mereka. ${ }^{96}$

c. Harga-diri (self-esteem). Harga-diri menunjukkan bahwa manusia memerlukan kehadiran orang lain yang dekat dalam hidup mereka. Hal ini karena manusia memerlukan penghargaan. Dengan kehadiran orang yang dekat, individu sudah cukup merasa dirinya diperlukan, dihargai, dan penting bagi orang lain. Perasaan itu merupakan dasar dari hargadiri yang sehat. Untuk menjadi keluarga harmonis, ibu, ayah, dan anakanak yang dicintai memerlukan kearifan dalam berbicara sehingga di antara mereka sama-sama merasa diperlukan, dihargai dan dimuliakan. ${ }^{97}$

d. Berbagi (Share). Untuk menjadi anggota keluarga yang saling mencintai antar anggota keluarga, maka sharing pendapat, rasa suka dan duka dengan anggota perlu dilakukan. Sebab, berbagi dengan seluruh anggota keluarga tentang apa saja akan meningkatkan tingkat keharmonisan di dalam bangunan keluarga itu. ${ }^{98}$

${ }^{94}$ Hassan, A. \& Ainon, M. Psikologi Asuhan Keluarga Jilid 1.( Fungsi Komunikasi. Kuala Lumpur, 2004).

${ }^{95}$ Martyn, K. K., Cherry, C. J. L., Villarruel, A. M., Cabriales, E. G., Zhou, Y., Ronis, D. L., \& Eakin, B. Mexican Adolescents' Alcohol Use, Family Intimacy, and Parent-Adolescent Communication.; Schrodt, P., Ledbetter, A. M., Jernberg, K. A., Larson, L., Brown, N., \& Glonek, K. (2009). Family communication patterns as mediators of communication competence in the parent-child relationship.

${ }^{96}$ Martyn, dkk., Ibid.; Schrodt, dkk., Ibid.

${ }^{97}$ Rangarajan, S. \& Kelly, L. Family Communication Patterns, Family Environment, and The Impact of Parental Alcoholism on Offspring Self-Esteem. (Journal of Social and Personal Relationships. Vol. 23, No. 4, 655-671. Sage Publications, 2006).

${ }^{98}$ Martyn, K. K., Cherry, C. J. L., Villarruel, A. M., Cabriales, E. G., Zhou, Y., Ronis, D. L., \& Eakin, B. Mexican Adolescents' Alcohol Use, Family Intimacy, and Parent-Adolescent 


\section{Etika Komunikasi dalam Keluarga}

Dengan mengaplikasikan etika dalam berkomunikasi seseorang individu akan dapat memelihara hubungan kekeluargaan mereka, aplikasi etika ini mampu memberi kesan yang positif terhadap diri seseorang individu untuk mengekalkan kesejahteraan hidup. Di antara etika komunikasi ${ }^{99}$ tersebut ialah :

a. Seorang individu dengan jujur seharusnya menceritakan perasaannya. Seseorang yang tidak jujur dengana perasaannya sama dengan tidak bertanggung jawab atas perasaannya sendiri. Hal ini akan menyebabkan hubungan menjadi tegang dan komunikasi menjadi negatif.

b. Perlunya komunikasi yang mendahulukan kepentingan dan tujuan bersama dan tidak mendahulukan kepentingan peribadi. Dalam situasi ini tidak boleh berbicara kerana hendak memperjuangkan perasaan diri sendiri saja.

c. Selama berkomunikasi perlu memberi informasi secara tepat, tidak boleh memberi informasi semu.

d. Tidak boleh sekali-kali mempunyai niat hendak menipu dan memperdaya orang lain sewaktu sedang berinteraksi.

e. Untuk menjaga keharmonisan sebuah keluarga setiap individu perlu menghindari dari terus mengumpat dan bergosip. Keadaan semacam ini akan meruntuhkan bagi keutuhan keluarga.

f. Apa yang dikatakan hendaknya sesuai dengan sikap dan perilaku.

g. Tidak boleh menimpali dan memotong pembicaraan orang lain yang sedang berbicara.

h. Apabila seorang individu sedang berbicara tentang sesuatu masalah, maka tidak wajar bagi individu yang lain menyebut bahwa masalahmasalah yang sedang dibicarakan individu yang sedang berbicara tersebut tidak ada kaitannya dengan apa yang dibicarakannya.

i. Tidak dibenarkan melakukan sesuatu yang dapat mengganggu individu lain yang sedang berbicara dan harus mendengarkannya dengan tenang.

j. Tidak dibenarkan berbicara tentang sesuatu yang negatif.

Communication.; Schrodt, P., Ledbetter, A. M., Jernberg, K. A., Larson, L., Brown, N., \& Glonek, K. Family communication patterns as mediators of communication competence in the parent-child relationship.; Crittenden, P. M. \& Dallos, R. All in the Family: Integrating Attachment and Family Systems Theories.

${ }^{99}$ Hassan, A. \& Ainon, M. Psikologi Asuhan Keluarga Jilid 1. 
k. Apabila sedang berkomunikasi atau berinteraksi dengan orang lain harus menghindari pembicaraan yang mencari cacat cela orang lain.

l. Apabila sedang berkomunikasi dengan orang lain, masalah yang paling penting untuk dilakukan ialah senantiasa menghargai orang yang sedang berbicara.

Dari 12 etika ini juga sangat penting dilakukan apabila berkomunikasi dengan sesama anggota keluarga, yakni antara suami dan isteri dan ibu-bapa dan anak-anak.

\section{Faktor Penyebab Terjadinya Masalah Komunikasi dalam Keluarga}

Faktor komunikasi merupakan kunci bagi kesuksesan hubungan dalam berkeluarga. Karena itulah komunikasi dalam keluarga harus dilakukan secara kontinyu dan dipelihara dengan baik. Sedikitnya ada tiga penyebab menonjol yang mengakibatkan terjadinya masalah komunikasi dalam keluarga, ${ }^{100}$ yaitu :

a. Kepercayaan bahwa anggota keluarga pasti sudah saling sepaham dan terampil berkomunikasi. Pemahaman yang seperti ini mengakibatkan komunikasi keluarga tidak dianggap serius untuk dibina dengan baik. Secara rutin memang sudah berkomunikasi tetapi lama kelamaan tidak lagi melibatkan jati dirinya dengan sepenuh perasaan dan kemauannya. Ini yang disebut komunikasi tanpa 'hati' atau komunikasi sebagai formalitas belaka. Antar anggota keluarga ada pembicaraan tapi hati mereka 'jauh'. Pada umumnya hal ini disebabkan adanya masalah pribadi yang tidak terselesaikan tapi dipaksa oleh kondisi sebagai satu keluarga di bawah satu atap maka komunikasi tapi dipaksa sebagai basa basi. 101

b. Komunikasi antar pribadi telah digantikan dengan alat hiburan yang menyita waktu untuk berkomunikasi. Sebagaimana disadari bahwa rumah telah dipenuhi dengan berbagai alat hiburan yang membantu menghilangkan kelelahan dan rasa capai setelah seharian penuh bekerja atau sekolah.

c. Komunikasi yang dimulai dengan persepsinya sendiri karena adanya kecenderungan untuk lebih banyak bicara daripada mendengar.

100 Ahira, A. Menghindari Perpecahan dan Menjaga Keharmonisan Keluarga.

101 Givertz, M., Segrin, C., \& Hanzal, A. The Association Between Satisfaction and Commitment Differs Across Marital Couple Types. (Communication Research. Vol. 36, No. 4, 561-584. Sage Publications, 2009).

30 JURNAL LISAN AL-HAL 
Mendengar juga punya seni bagaimana ia memperhatikan inti berita, mempersepsi dengan baik, merespon dengan tepat.

\section{F. Simpulan}

Kebahagiaan dan keharmonisan dalam rumah tangga bersumber dari rasa cinta, kematangan emosional, dan intensitas komunikasi yang terbangun dari masing-masing individu dalam rumah tangga tersebut. Ciri-ciri adanya rasa cinta terdapat hubungan yang harmonis antara suami dan isteri. Keharmonisan suami-isteri, di samping sebagai sebuah bentuk karakter dan kepribadian orang tua juga merupakan sarana pembentuk karakter dan kepribadian anak. ${ }^{102}$

Keharmonisan dalam rumah tangga yang bersumber dari kerukunan masing-masing individu dalam rumah tangga yang telah melaksanakan tugas, fungsi, dan tanggung jawabnya merupakan manifestasi dari sebuah kematangan emosional dari masing-masing individu dalam rumah tangga tersebut. Di sisi lain, keharmonisan dalam rumah tangga adalah faktor intensitas komunikasi dalam keluarga yang berjalan efektif. Intensitas komunikasi dalam rumah tangga memiliki pengaruh yang cukup besar terhadap baik tidaknya keharmonisan hubungan dalam keluarga. Sebaliknya, komunikasi yang tidak efektif sering menjadi penyebab rusaknya keharmonisan suatu hubungan dalam keluarga. ${ }^{103}$

Menjalin komunikasi yang baik antar anggota keluarga tidak semudah membalikkan telapak tangan. Mengusahakan, memelihara, dan mempertahankan agar komunikasi dapat terus berjalan baik, menjadi tanggung jawab setiap anggota keluarga. Perbedaan pendapat, kebutuhan, sifat, atau kemampuan masing-masing anggota keluarga bisa menjadi penyebab ketidaklancaran komunikasi dalam keluarga. ${ }^{104}$

\section{DAFTAR PUSTAKA}

Adler, M.A. German Unification as a Turning Point in East German Woman's Life Course : Biographical Changes in Work and Family

102 Ramadhan, T. Keharmonisan Keluarga dan Kesuksesan Anak. http://tarmizi.wordpress.com/ 2009/01/26/keharmonisankeluargadankesuksesananak, 2009).

103 Ahira, A. Menghindari Perpecahan dan Menjaga Keharmonisan Keluarga.

104 Schrodt, P., Ledbetter, A. M., Jernberg, K. A., Larson, L., Brown, N., \& Glonek, K. Family communication patterns as mediators of communication competence in the parentchild relationship. 
Roles. Sex Roles: A Journal of Research. http://www.looksmart.com. 2002.

Ahira, A. Menghindari Perpecahan dan Menjaga Keharmonisan Keluarga. http://www.anneahira.com/menjaga-keharmonisan-keluarga.htm. 2010.

Allen, T.D. Applicant Gender and Family Structure : Effects on Perceived Relocation Commitment and Spouse Resistance. Sex Roles : A Journal of esearch. http://www.looksmart.com, 2002.

Aron, A. \& Henkemeyer, L. Marital Satisfaction and Passionate Love. Journal of Social and Personal Relationships. Vol. 12, No. 1, Sage Publications. 1995.

Aron, A., Paris, M., \& Aron, E. N. Falling and Love Prospective Studies of Self Concept Change. Journal of Personality and Social Pasychology. 1995.

Carroll, J. S., Badger, S., \& Yang, C. The Ability to Negotiate or the Ability to Love? : Evaluating the Developmental Domains of Marital Competence. Journal of Family Issues. Vol. 27, No. 7, Sage Publications. 2006.

Chaplin, C.P. Kamus Lengkap Psikologi. Terjemah. Jakarta: PT. Raja Grafindo Persada. 2000.

Crisp R. J. \& Turner R. N. Essential Social Psychology, London: Sage Publications. 2007.

Crittenden, P. M. \& Dallos, R. All in the Family: Integrating Attachment and Family Systems Theories. Clinical Child Psychology and Psychiatry. Vol. 14, No. 3. Sage Publications. 2009.

DeMaris, A., Mahoney, A., \& Pargament, K. I. Sanctification of Marriage and General Religiousness as Buffers of the Effects of Marital Inequity. Journal of Family Issues. Vol. 31, No. 10, Sage Publications. 2010.

Fisher, H. Why We Love: The Nature and Chemistryof Romantic. New York. Holt. 2004.

Frisco, M. L. \& Williams, K. Perceived Housework Equity, Marital Happiness, and Divorce in Dual-Earner Households. Journal of Family Issues. Vol. 24, No. 1. Sage Publications. 2003.

Givertz, M., Segrin, C., \& Hanzal, A. The Association Between Satisfaction and Commitment Differs Across Marital Couple Types. Communication Research. Vol. 36, No. 4. Sage Publications. 2009.

Gunarsa, S.D dan Gunarsa, Y.S.D. Psikologi Praktis Anak, Remaja dan Keluarga. Cet. 7 Jakarta: PT. BPK Gunung Mulia. 2004.

$32 \mid$ JURNAL LISAN AL-HAL 
Hasanat, N. Apakah Perempuan lebih Depresif dari Laki-laki? Laporan Penelitian (tidak diterbitkan) Yogyakarta: Fakultas Psikologi UGM. 1994.

Hassan, A. \& Ainon, M. Psikologi asuhan Keluarga jilid 1. Fungsi Komunikasi. Kuala Lumpur. 2004.

Huber, C. H., Navarro, R. L., Womble, M. W., \& Mumme, F. L. Family Resilience and Midlife Marital Satisfaction. The Family Journal: Counseling and Therapy for Couples and Families. Vol. 18, No. 2, Sage Publications. 2010.

Hurlock, E. Psikologi Perkembangan. Suatu Pendekatan Sepanjang Rentang Kehidupan. (Terjemah). Edisi kelima. Jakarta : Erlangga. 1994.

Jones, C. J. \& Meredith, W. Developmental Paths of Psychological Health From Early Adolescence to Later Adulthood. Psychology and Aging. Vol. 15, No. 2, American Psychological Association, Inc. 2000.

Kidman, A. Family Life; Adapting to Change A self Help Manual. Biochemical \& general service, Sydney. 1995.

Knauth. D. G. Family Secrets: An Illustrative Clinical Case Study Guided by Bowen Family Systems Theory. Journal of Family Nursing, Vol. 9, No. 3, Sage Publications. 2003.

Lambrecht, J. \& Lievens, J. Pruning the Family Tree: An Unexplored Path to Family Business Continuity and Family Harmony. Family Business Review, Vol. 21, No. 4, Sage Publications. 2008.

Liddle, H. A., Santisteban, D. A., Levant, R. F., \& Bray, J. H.. Family Psychology; Science-Based Interventions. American Psychological Association. Washington, DC. 2002.

Lodro, W. Keharmonisan Keluarga Dengan Perkawinan Bahagia. http://www.kainsutera.com/info-remaja/keharmonisan-keluargadengan-perkawinan-bahagia.html 2010.

Lucas, T., Parkhill, M. R., Wendorf, C. A., Imamoglu, E. O., Weisfeld, C. C., Weisfeld, G. E., \& Shen, J. Cultural and Evolutionary Components of Marital Satisfaction : A Multidimensional Assessment of Measurement Invariance. Journal of Cross-Cultural Psychology. Vol. 39, Sage Publications. 2008.

Mandara, J. \& Murray, C. B. Effects of Parental Marital Status, Income, and Family Functioning on African American Adolescent Self-Esteem. Journal of Family Psychology. Vol. 14, No. 3, American Psychological Association, Inc. 2000.

Martyn, K. K., Cherry, C. J. L., Villarruel, A. M., Cabriales, E. G., Zhou, Y., Ronis, D. L., \& Eakin, B. Mexican Adolescents' Alcohol Use, Family Intimacy, and Parent-Adolescent Communication. Journal of Family 
Nursing. Vol. 15, No. 2, Sage Publications. 2009.

Matsunaga, M. \& Imahori, T. D. Profiling Family Communication Standards : A U.S.-Japan Comparison. Communication Research. Vol. 36, No. 1, Sage Publications. 2009.

Niska, K. J. Mexican American Family Survival, Continuity, and Growth: The Parental Perspective. Nursing Science Quarterly, Vol. 14 No. 4. Sage Publications. 2001.

Patrick, S., Sells, J. N., Giordano, F. G., \& Tollerud, T. R. Intimacy, Differentiation, and Personality Variables as Predictors of Marital Satisfaction. The Family Journal: Counseling and Therapy for Couples and Families, Vol. 15, No. 4, Sage Publications. 2007.

Ramadhan, T.. Keharmonisan Keluarga dan Kesuksesan Anak. http://tarmizi.wordpress.com/2009/01/26/keharmonisankeluarga dankesuksesananak 2009.

Rangarajan, S. \& Kelly, L. Family Communication Patterns, Family Environment, and The Impact of Parental Alcoholism on Offspring Self-Esteem. Journal of Social and Personal Relationships. Vol. 23, No. 4, Sage Publications. 2006.

Riyawati, D. Y. Perbedaan Kematangan Emosi pada Wanita Usia 25-35 Tahun Ditinjau dari Tingkat Pendidikan dan Usia Memasuki Perkawinan. Fakultas Ilmu Pendidikan, Universitas Negeri Semarang. 2006.

Schrodt, P., Ledbetter, A. M., Jernberg, K. A., Larson, L, Brown, N., \& Glonek, K. Family communication patterns as mediators of communication competence in the parent-child relationship. Journal of Social and Personal Relationships. Vol. 26, No. 6-7. Sage Publications. 2009.

Snyder, C.R. \& Shane, J. L. Positive Psychology The Scientific And Practical Exploration Of Human Strengths. 2006.

Srivastava, S., John, O. P., Gosling, S. D., \& Potter, J. Development of Personality in Early and Middle Adulthood: Set Like Plaster or Persistent Change?. Journal of Personality and Social Psychology. Vol. 84, No. 5, American Psychological Association, Inc. 2003.

Sternberg, R. J. A Triangular Theory of Love. Psychology Review, 93, 1986.

Sternberg, R. J. What is the common thread of creativity? Its dialectical relation to intelligence and wisdom. American Psychologist, 56, 2001.

Syamsu Yusuf. Psikologi Perkembangan Anak dan Remaja. Bandung: PT. Remaja Rosdakarya. 2004.

34 JURNAL LISAN AL-HAL 
Thomas, M. \& Bailey, N. Out of Time: Work, Temporal Synchrony and Families. Sociology. BSA Publications Ltd. Vol. 43, No. 4, Sage Publications. 2009.

Walgito, Bimo. Bimbingan \& Konseling di Sekolah. Yogyakarta: Andi Offset. 2004.

Widhiati, G. W. Hubungan antara Kepercayaan dan Keharmonisan Keluarga.http://keluargaharmonis.com/hubungan-antarakepercayaan-dan-keharmonisan-keluarga. 2010. 
"Kebahagiaan dan Keharmonisan Rumah Tangga"

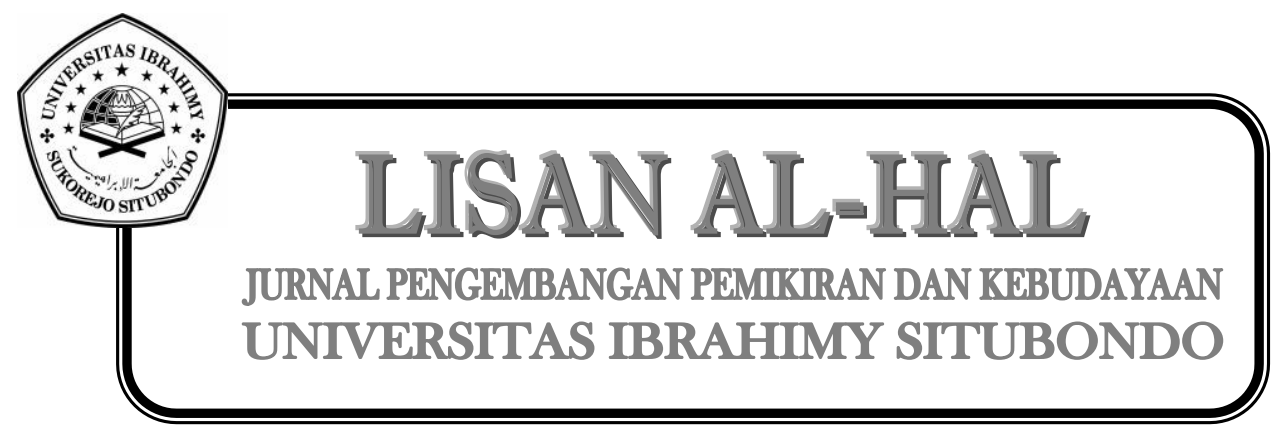

36 JURNAL LISAN AL-HAL 